ISBN 978-93-84468-92-7

International Conference on Issues in Education, Literature, Humanities and Social Sciences

(IELHSS-2017)

Kuala Lumpur (Malaysia) Jan. 4-5, 2017

\title{
Factors Affecting Chinese Consumer Behavior to purchase Phoyok Herbal Balm
}

\author{
Dr. Chinnaso Visitnitikija, and Yisha Qin \\ Post graduate school of Business Administration, Kasembundit University, Bangkok
}

\begin{abstract}
The primary purpose of this study is to determine factors of affecting Chinese consumer behavior and marketing mix to purchase Phoyok Herbal Balm. This study was the quantitative study with the samplings of the study were 392 Chinese consumer who purchased Phoyok herbal balm by using a questionnaire as a tool. The statistics used for data analysis were percentage, mean, standard deviation, Chi-Square, and regression analysis.

On the basis of the results of this study, it can be concluded that most of 392 respondents were females, age 25-35 years old, marriage status, bachelor degree graduated, average monthly income 15,000-25,000 baht, traveled to Thailand, friends recommended, and averaged spending of 798.94 baht for 2 bottles.

The overall picture of the opinions of factors of marketing mix affecting Chinese consumers to purchase Phoyok herbal balm were in high level with following details, such as popularity, effective resulted, prices appropriate to product, convenient to purchase, advertising through multimedia, and discount during holidays seasons. The test of hypothesis revealed that the personal different, such as gender, age, level of education, and marital status affected the Chinese consumer behavior on purchasing Phoyok Herbal Balm at significant level 0.05. Factors of marketing mix, such as products shape, color, and packages designed, and distribution channel correlated to consumer behavior on purchasing Phoyok herbal balm at significant level 0.05.

Recommendations from the study were that manufacturer should develop products shape, color, modern looking packages design, appropriate prices with quality of products, easy to purchase, and marketing promotion with free samples.
\end{abstract}

Keywords: Affecting Behavior

\section{Introduction}

Drugs and home medicines recipes point out to wax which used to prevent swollen, besides solving the swell, also commonly used for inhalation to relieve dizziness and nausea, relieve stomach pain as well, and this is an oily substance that has a pleasant smell and that is used for healing, smoothing, or protecting the skin, something that gives comfort or support which called balm.

The article above, the retrospective event in 2343 BC. When Chinese herbal medicine doctor named Aw Che Kin set out to seek a fortune. Along the way, travelling on the ship he suffered seasickness due to heavy waves to Myanmar. He opened small pharmacies and making a living there. Giving the birth of 3 sons, one of his son named Boom Par and another named Boom Haw. The British took over Burma which became English's colonized then. Boom Par had learnt herbal medicine from his father and continued to his father business after his father passed away and Boom Haw was sent back to China.

One of the things that Aw Che Kin, left to his son was a recipes which came from the Court of the Emperor of China which was an ancient Chinese medicine, which was useful in solving external pain, relieving nausea, and general malaise. Boom Par was concentrated on learning more knowledges, and doing research trials to increase the benefit of his own medications and became a popular medicine from general users. When his business was increasing in benefit he sent a letter to his brother Boom Haw asked his brother to come back to help with the business. With the nature of enterprising and leadership of Boom Haw combined with pharmaceutical ability of Boom Par, both brothers were making a bottle of powder medicine as a widely known Later, after World War 1, the 
two brothers had fled Myanmar and migrated to Singapore. Their medicine had been expanding to more than 70 countries around the world, and became known in Thailand as Yah-mong which name reflects the origin of the medicine of Myanmar.

The balm has long been in the history, therefore it's no surprise that Balm is a product that has been accepted and memories of consumers. Due to the Balm as medicines and herbal consist of soft, liquid, both yellow and white color, the other by the aromatic ingredients used to relieve dizziness, nausea, vomiting, including apply to skin tissue and massage to relieve pain, bruised, swollen, insect bites and stings.

Currently, Chinese tourists entering Thailand have increased every year. The number of Chinese tourists visiting Thailand growth rate in year 2557 and 2558 with the number of Chinese tourists 4,636,298 and 7,934,719 people (Department of tourism of Thailand , 2559) in the year 2558 Chinese tourists have spent 371,000 million baht in Thailand . The herb is a product that Chinese tourists favorite, because of Phoyok balm is using natural ingredients products that contains herbs.

From the above history, research was interested in studying the factors that affecting Chinese consumer behavior and marketing mix to purchase Phoyok Herbal Balm. The results of the study will be useful for the Phoyok balm manufacture to improve and develop the products and distribution strategy in accordance with the requirement of the consumer.

\section{The Purpose of the Study}

1. To study Chinese consumer behavior on buying Phoyok herbal balm.

2. To study marketing mix affecting Chinese consumer on buying Phoyok herbal balm.

\section{Conceptual framework of the study}

From study of above, researcher selected marketing mix and consumer behavior theory to summarize for conceptual framework of the study.

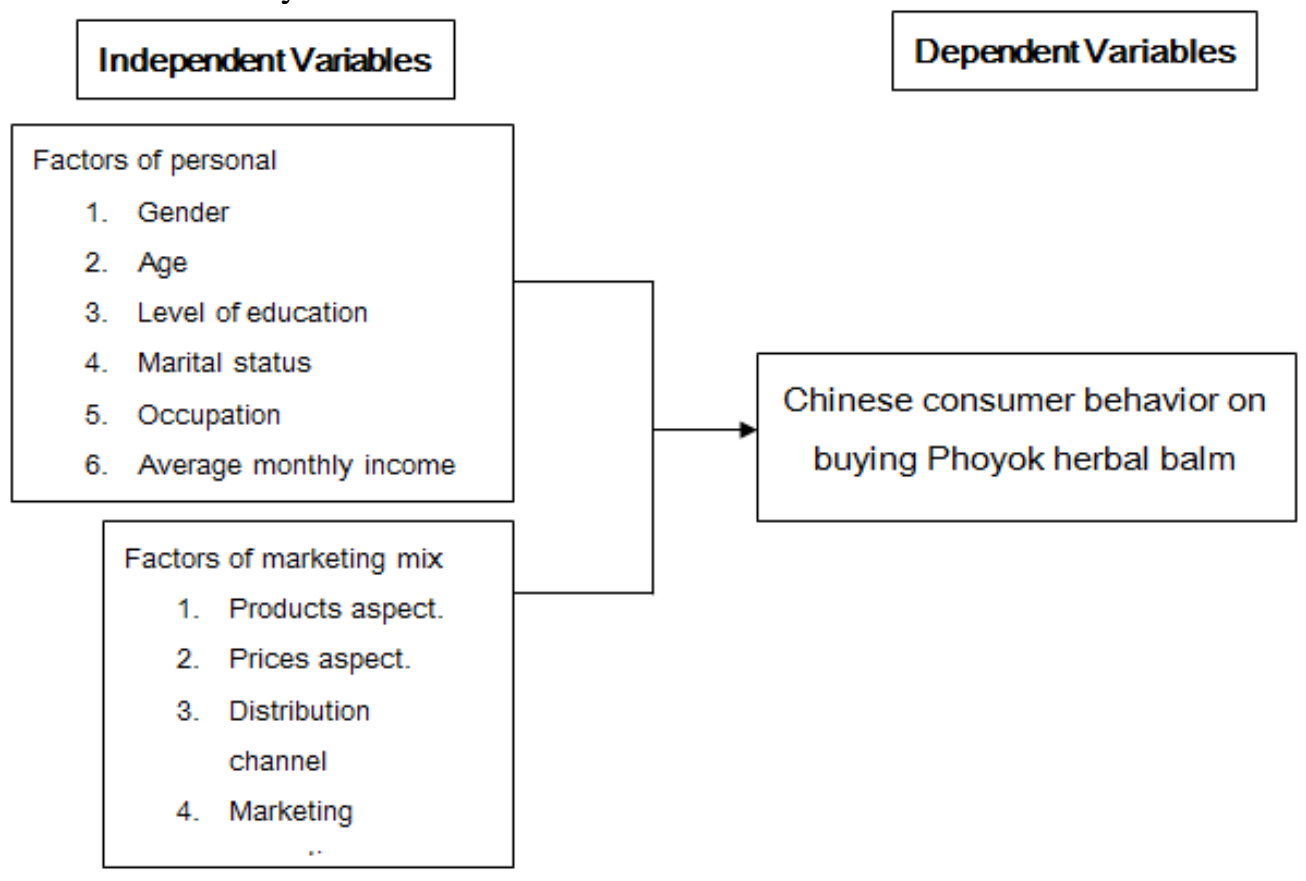

\section{Research Methodology}

\section{Sample selection}

The samplings of the study were 392 Chinese consumers who purchased Phoyok herbal balm.

\section{Data collection procedure}

The questionnaires were distributed to sample of 392 Chinese consumer who purchased Phoyok herbal balm. A total of 392 usable questionnaires were returned back to the researcher, yielding a 100 percent response rate and no missing data. 


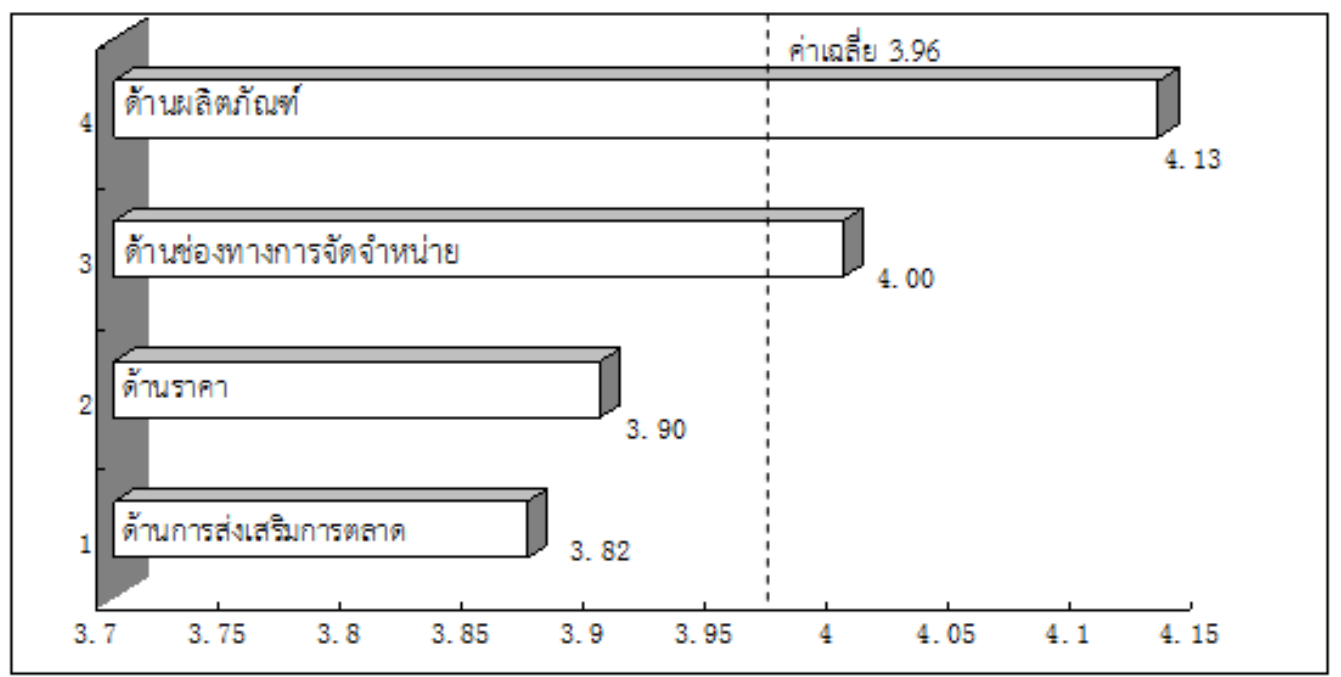

Fig. 1: The results of the study of marketing factors affecting Chinese consumer on buying Phoyok herbal balm with overall picture of the opinions as shown.

From figure 1: shows the overall picture of the opinions of marketing mix affecting Chinese consumer behavior on buying Phoyok herbal balm were at high level in descending order, such as products aspect $(\bar{x}=4.13)$, distribution channel aspect $(\bar{x}=4.00)$, prices aspect $(\bar{x}=3.90)$, and marketing promotion aspect $(\bar{x}=3.82)$.

TABLE I: shows the test of hypothesis with regression value of the important of marketing mix correlated to Chinese consumer behavior on buying Phoyok herbal balm

\begin{tabular}{|c|c|c|c|c|c|c|}
\hline Factors of marketing mix & $\mathrm{B}$ & Std. error & Beta & $\mathrm{t}$ & Sig. & results \\
\hline (constant) & 1161.446 & 1426.282 & & .814 & & \\
\hline \multicolumn{7}{|c|}{ Products aspect } \\
\hline Products reputation & -187.873 & 283.364 & -.040 & -.663 & .508 & No relationship \\
\hline Effective resulted & 389.010 & 289.782 & .087 & 1.342 & .180 & No relationship \\
\hline Packages designed & 855.029 & 273.594 & .189 & 3.125 & $.002 * *$ & relationship \\
\hline Size and volume & -209.191 & 285.053 & -.044 & -.734 & .463 & No relationship \\
\hline $\begin{array}{l}\text { Label with the detail of balm with } \\
\text { address of manufacture }\end{array}$ & -38.727 & 292.775 & -.009 & -.132 & .895 & No relationship \\
\hline FDA of GMP approval & -198.610 & 252.389 & -.049 & -.787 & .432 & No relationship \\
\hline \multicolumn{7}{|c|}{ Prices aspect } \\
\hline Prices appropriate to product quality & 431.302 & 248.371 & .101 & 1.737 & .083 & No relationship \\
\hline Products with clearly label & 221.241 & 222.831 & .057 & .993 & .321 & No relationship \\
\hline Discount prices & 37.163 & 229.992 & .010 & .162 & .872 & No relationship \\
\hline \multicolumn{7}{|c|}{ Distribution channel aspect } \\
\hline Products offered at retail stores & 772.771 & 244.815 & .194 & 3.157 & $.002 * *$ & relationship \\
\hline Products available to purchase online & 1036.074 & 247.754 & -.237 & 4.182 & $.000 * *$ & relationship \\
\hline $\begin{array}{l}\text { Products available on tour bus and } \\
\text { plane }\end{array}$ & 743.110 & 225.838 & .192 & 3.290 & $.001 * *$ & relationship \\
\hline Products available at dealers & 416.609 & 258.295 & .107 & 1.613 & .108 & No relationship \\
\hline \multicolumn{7}{|c|}{ Marketing promotion aspect } \\
\hline Advertising through newspapers & 542.335 & 235.033 & .154 & 2.307 & $.022 *$ & relationship \\
\hline Advertising through Internet & -13.731 & 251.958 & -.003 & -.054 & .957 & No relationship \\
\hline Free samples & 278.588 & 226.641 & .075 & 1.229 & .220 & No relationship \\
\hline
\end{tabular}

*Significant level 0.05

Comparison of correlation between marketing mix and consumer behavior on buying Phoyok herbal balm revealed that marketing mix of products aspect, such as products shape, color, and packages design (0.002), distribution channel aspect (0.002), available online (0.000), available on tour buses and air plane (0.001), marketing promotion such as advertising through magazines and newspapers (0.022) correlated to consumer behavior on buying Phoyok herbal balm at significant level 0.05 . 


\section{Summary of the Study of Consumer Behavior on Buying Phoyok Herbal Balm}

The overall picture of the opinion of marketing mix affecting consumer behavior on buying Phoyok herbal balm were at high level with details as followed.

Products aspect, products reputation of herbal, effective results, packages designed with beautiful color, and GMP or FDA approval of the products.

Prices aspect, prices appropriated to products quality, clearly display prices accurately, and prices reduction for consumer.

Distribution channel, available at retail stores, Internet, and on the tour bused and airplanes.

Marketing promotion aspect, advertising through magazines and newspapers, website, free samples, and discount during holidays seasons.

\section{Suggestion for the Study}

Recommendations from the study were that administrative officers of the company should emphasize on modern design packages with beautiful color, appropriate prices suitable to quality, add more distribution channels in order for consumer convenient, and free samples.

\section{References}

[1] Chutima Vitayalai. (2555). Consumer behavior on buying medicine from pharmacy stores in Cholburi capital district, Thesis, Master of Business Administration, Sukho Thai Thammatiratch University.

[2] Tiva Pongthon \& Associate. (2554). Consumer behavior. Patanavichagarn. Bangkok.

[3] Nisarat Cantorn. (2555). Consumer behavior on buying traditional herbal medicine from pharmacy stores in Chiengmai province.

[4] Piyaporn Maruhkapan. (2553). Factors of marketing mix affecting consumer on buying cough Drops in Bangkok area. Thesis. Master of Business Administration. Lad Krabang Technology University.

[5] Panisa Lunchanont. (2548). Marketing principle. Business World, Bangkok/

[6] Voraprot Ratanapong. (2547). Factors affecting consumer behavior on using muscle pain Medicine in Bangkok. Thesis, Master of Business Administration, Kasetsart University.

[7] Siriwan Saerirat \& Associate. (2541). Business research. Petchasanghanglorkthurakit, Bangkok.

[8] Siriwan Saerirat \& Associate. (2546). New era of marketing management. Diamond in Business World, Bangkok.

[9] Saeree Vongmonta. (2546). Principles of Advertising. Thammasarn, Bangkok.

[10] Suthida Pagagrong. (2555). Factors related to consumer behavior on choosing pharmacy stores in Nakornsrithammarach province. Thesis, Sukho Thai Thammatiratch University.

[11] Mowen, JC. \& Minor, M. 1988. Consumer behavior (5th Ed.). Upper Saddle River, NJ: Prentice-Hall. 